\title{
Editorial vol 74(4) December 2021
}

\section{B. N. Chakraborty ${ }^{1,2}$}

(c) Indian Phytopathological Society 2021

Dear Readers,

The fourth issue, volume 74 of Indian Phytopathology for October-December, 2021 is ready. In this issue there are thirty six articles including three review articles, twenty research articles, nine short communications and four new reports.

In the first review article, Dr. R. Viswanathan has emphasized on the current status of research on genome wide association studies in sugarcane host pathogen system for disease resistance. In the second review article, Dr. T.S. Thind has given a perspective on changing trends in discovery of new fungicides. Dr. L. Manjunatha has presented a comprehensive review on the current status and control strategies of Pigeon pea sterility mosaic virus.

Efficacy of different agricultural wastes and casing materials on the growth and yield of Macrocybe gigantea and biological efficiency, nutrient contents and antioxidant activity of Pleurotus pulmonarius enriched with Zinc and Iron were evaluated. Molecular identification and pathogenic variability in $\mathrm{F} 2$ generation of Cochliobolus sativus and pathogenic variability among Colletotrichum kahawae population from major coffee growing regions of Ethiopia have been presented. Molecular and phenotypic analyses of Bipolaris species infecting wheat and rice have also been done. Heterothallism among spatiotemporally diverse Colletotrichum lindemuthianum isolates and its implication in common bean anthracnose resistance breeding in the Northwestern Himalayan region have been explained. Morpho-cultural, physiological and molecular characterization of Sphaceloma ampelinum causing anthracnose of grapes in temperate region of India and its management has been reported. Antifungal activity of commercial perfumes

B. N. Chakraborty

bncnbu@gmail.com

Indian Phytopathological Society, New Delhi, India

2 Department of Biological Sciences, Aliah University, New Town, Kolkata, India and their fragrance against Alternaria solani, a leaf blight pathogen of potato has been analysed.

Field based assessment of yield-related traits and flowering response in Zea mays towards Southern corn leaf blight and Potato late blight incidence by Phytophthora infestans and severity influenced by cropping practices adopted in North Wollo, Eastern Amhara, Ethiopia have been presented. Organic bio-products have been applied through drip irrigation against Tylenchulus semipenetrans in citrus. Trichoderma isolates from rhizosphere of coffee have been evaluated against Gibberella xylarioides. Effect of biofumigation by Brassica juncea on Sclerotium rolfsii causing collar rot in betelvine has been documented. Nano-chelated silicon fertilizer has been used for the management of Meloidogyne javanica in tomato. Strategies for management of root-knot nematode in cucumber through seed treatment with multifarious beneficial microbes in polyhouse under protected cultivation has been developed. Efficacy of Isopyrazam and Difenoconazole against pomegranate diseases under field condition have been worked out. Fluorescent Pseudomonas has been characterized with its bio-control potential against Ralstonia solanacearum. Association of Tomato leaf curl Karnataka virus and satellites with enation leaf curl disease of a new ornamental host (Pseuderanthemum reticulatum) for begomovirus infecting tomato has been demonstrated and Tomato leaf curl Palampur virus associated with leaf curl and yellowing disease of watermelon has been characterized. Establishment of virus-free elite mother orchards of apple in the Trans-Himalayan region of India has been documented.

Resistance in black pepper against Phytophthora infection was evaluated using peroxidase activity as a marker. Puccinia graminis f. sp. tritici races were identified on wheat and Berberis spp. in northern Turkey. Growth inhibitory potential of eudicot-based plant preparations (Lavandula angustifolia, Matricaria chamomilla and Saponaria officinalis) against plant pathogenic fungi (Phytophthora infestans, Rhizoctania solani, Fusarium oxysporum. $f$. sp. lycopersici and Macrophamina phaseolina) have been presented. Identification of resistance sources against frogeye 
leaf spot (FLS) disease of soybean caused by Cercospora sojina under hot spot conditions of Uttarakhand hills have been discussed. Klebsiella oxytoca strains associated with wetwood disease of Morus trees were identified and characterized. Recombinant inbred lines were developed and screened for bacterial wilt resistance of brinjal caused by Ralstonia solanacearum. Molecular identification of citrus greening bacterium associated with Kinnow Mandarin has been done. Molecular identification of brinjal little leaf disease associated with Solanum melongena showed 99-100\% similarity with the 'Candidatus Phytoplasma trifolii' strain which was based on sequence comparison analysis of 16SrRNA, rp and secY gene. Molecular characterization of the 3' end of Citrus tristeza virus genome from Oman have also been carried out.

First reports of Lasiodiplodia theobromae causing brown rot of jackfruit (Artocarpus heterophyllus) in Philippines, Lactarius sinozonarius from Jammu and Kashmir, India, Phoma sp. in small cardamom (Elettaria cardamomum) from
Western Ghats, India and charcoal rot caused by Macrophomina phaseolina on Kalanchoe blossfeldiana in Iran have been recorded.

Authors, reviewers, editorial board members, executive council members of Indian Phytopathological Society and business manager who have put in lot of efforts to bring out timely publication of this issue are gratefully acknowledged. Authors are requested to submit the best research/review articles to Indian Phytopathology to maintain its quality high standard.

Prof. B. N. Chakraborty

Chief Editor, Indian Phytopathology

Publisher's Note Springer Nature remains neutral with regard to jurisdictional claims in published maps and institutional affiliations. 